\title{
Attitudes of women living in Otwock County toward breast cancer risk - prophylactic activity level
}

\begin{abstract}
According to ICD C-50 breast cancer (or disease of the nipple) is the second most frequent cause of death among women in Poland. It also ranks first among tumors. The number of cancer cases is on the rise, which is due to the fact that women are not involved in voluntary protection programs, they do not conduct breast self-examinations systematically and the fact that breast tumors are usually detected at an advanced stage. In order to improve these statistics, some anti-tumor programs, focusing on breast cancer, regular self-examination need to be implemented. It would definitely decrease the number of cancer cases and drive down the mortality indexes.

The authors of this article analyzed the health-seeking behaviors among female residents of Otwock county, paying special attention to the risk of breast cancer factors and disease prevention. This work is based on research conducted in 2014 , looking at 69 women, residents of city of Otwock and Otwock area. An anonymous questionnaire designed by the authors of the study was handed out to the participants and the results were later subject to a statistical analysis.

The findings of the study suggest what follows: (i) gynecologists are not engaged enough in breast cancer prevention programs; (ii) women rarely conduct breast self-examinations, even though they know they have to do it at least once a month; (iii) women participate in preventive breast examinations relatively often; (iv) women would not be against mandatory mammography screenings; (v) the place of residence had no significant influence over one's attitude toward prophylaxis; (vi) health education for girls should become a subject in junior high schools (gimnazjum in Polish).
\end{abstract}

Keywords: Breast cancer, Breast cancer prophylaxis, health-seeking behaviors among women, Otwock county.

DOI: $10.1515 /$ pjph-2016-0013

\section{INTRODUCTION}

For the last 20 years, breast cancer has been causing an increase in mortality indexes among Polish women. It is estimated that some 15000 women develop breast cancer every year and in case of some 5000-5500 women, breast cancer is the primary cause of death $[1,2]$. In the $1990 \mathrm{~s}$, breast tumors were the major cause of some $14 \%$ of all deaths [3-5], while in the 2010 , it was $21 \%$ (standardized mortality ratio, including sex, place of residence, cause of death in 2010 for every 100.000 people) [6].

In 2010, some 5226 women died because of breast cancer in Poland, which translates into $6 \%$ of the overall number of tumor-related deaths and $13 \%$ of the female cancer-related death rates [6].

Every year, Polish National Cancer Registry (PL: Krajowy Rejestr Nowotworów) registers an increasing number of breast cancer cases. Similar patterns might be noticed in Mazovian Voivodeship. According to the Registry, some 19939 women, aged 20-85+ developed breast cancer between 2003 and 2012, in Mazovian Voivodeship only. Some 7516 women died because of it. In Otwock county, 427 women developed this condition and 168 died which means that in case of $39 \%$ of women, breast cancer was a primary cause of death [1,2].

The data collected by National Cancer Registry shows an increase of $112.5 \%$ in terms of breast cancer development in 2012 (when compared to 2003) - in 2003, some 24 women developed the condition, while in 2012 it was 51 women. When it comes to mortality rates, they have decreased in 2012, the number was $58.3 \%$ lower (10 deaths) than in 2003 (24 deaths). This decrease, even though it was accompanied by an increase in breast cancer development cases between 2003 and 2012, might be due to the fact that a specialist cancer treatment center was built in Otwock. The center employs highly qualified doctors, diagnostic equipment and highly specialized breast cancer treatment procedures. At the same time, the number of deaths in Mazovian Voivodeship has increased.

Looking at the number of breast cancer cases in a yearby-year perspective, it was increasing, both in Mazovian Voivodeship and Otwock county. These findings are similar to what was recorded in other parts of Poland. Between 2003 and 2012, the numbers of cancer development cases and cancer-related deaths were as follows. 
TABLE 1. Statistics concerning cancer development cases in Mazovian Voivodeship and Otwock county between 2003 and 2012.

\begin{tabular}{lcccc}
\hline \hline \multicolumn{3}{c}{ Cancer development cases } & \multicolumn{2}{c}{ Deaths } \\
\hline & $\begin{array}{c}\text { Mazovian } \\
\text { Voivodeship }\end{array}$ & $\begin{array}{c}\text { Otwock } \\
\text { county }\end{array}$ & $\begin{array}{c}\text { Mazovian } \\
\text { Voivodeship }\end{array}$ & $\begin{array}{c}\text { Otwock } \\
\text { county }\end{array}$ \\
\hline 2003 & 1565 & 24 & 686 & 24 \\
\hline 2004 & 1731 & 29 & 722 & 9 \\
\hline 2005 & 1765 & 34 & 725 & 16 \\
\hline 2006 & 1823 & 32 & 715 & 13 \\
\hline 2007 & 2064 & 57 & 724 & 19 \\
\hline 2008 & 2007 & 48 & 779 & 19 \\
\hline 2009 & 2271 & 52 & 741 & 15 \\
\hline 2010 & 2102 & 44 & 794 & 29 \\
\hline 2011 & 2162 & 56 & 799 & 14 \\
\hline 2012 & 2447 & 51 & 831 & 10 \\
\hline
\end{tabular}

An early detection of breast cancer hugely increases the chances of a successful recovery and proves extremely important for fighting the disease. Knowing the rules of breast self-examination, conducting self-examinations regularly, the awareness of risk factors, breast examinations conducted by the gynecologist, as well as active participation in prophylactic exams designed for women with hereditary risks or to women at the age of the highest risk. Such measures can lower the number of cancer development cases, as well as the number of breast cancer-related deaths.

\section{AIM}

The authors of this work attempted to assess the knowledge of women about preventive measures and checking, which measures women take and why they do so.

\section{MATERIAL AND METHODS}

The study was conducted between September and October 2014. The authors looked at 69 women, residents of Otwock and the county (including cities like Otwock, Józefów, Karczew, as well as rural areas). The authors used a self-designed questionnaire containing 31 questions concerning the knowledge about breast cancer detection or respondents knowledge about the tumor itself. The questionnaire included 6 questions about age, place of residence, educational level, number of births given and the age at which the first child was born. The participation was voluntary and anonymous and the participants were chosen at random.

\section{Study findings and discussion}

The study group consisted of women of various ages. Most of the participants were women aged 56-65 (27.1\%), while women older than 65 constituted the smallest group (around $12 \%$ ). Some $20 \%$ of study participants were women aged $36-45$, while another $19 \%$ were women aged $25-35$. The study group also consisted of women aged 46-55 (22\%).

Almost a half of the respondents were residents of Otwock $(49.2 \%)$, while others lived in different parts of Otwock county $(15.3 \%)$ or in the countryside $(35.6 \%)$. Women with higher education were the most numerous group $(44.1 \%$,) those with secondary education constituted $39 \%$, another $10.2 \%$ declared professional education and some $7 \%$ of the respondents had basic education only.

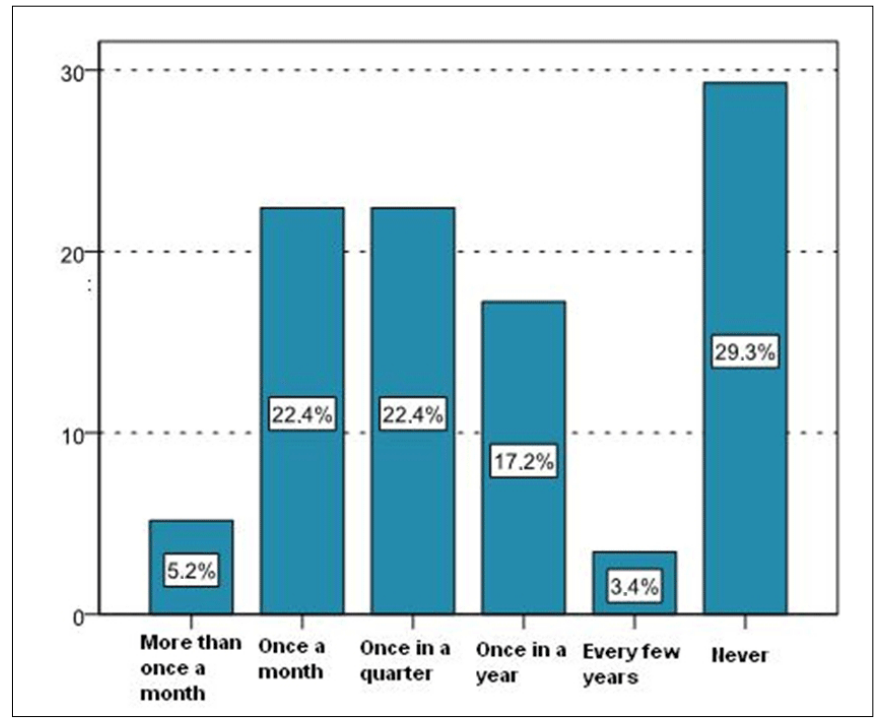

FIGURE 1. The frequency of breast self-examination among pharmacists from Otwock county.

Most of the respondents were professionally active (66.1\%), while others were not - retired women (19\%), women receiving unemployment benefits $(5 \%)$, university students $(3 \%)$, women receiving pension $(2 \%)$. Some $24 \%$ of the respondents have never given birth to a child, $15 \%$ had one child, $32 \%$ had two children, while $29 \%$ of the respondents had three or more children. Most women gave birth to their first child between 22 and 26 (22 women).

A significant number of the respondents have never done breast self-examination $(29.3 \%)$. Most women have done it once a month $(22.4 \%)$ or once in a quarter $(22.4 \%)$. There were lots of women who did it once a year (17.2\%). Also, some 5\% of the respondents do the self-examination a few times a month.

There were no correlations between the frequency of breast self-examinations and women's age $(p=0.717)$, place of residence $(p=0.249)$, education $(p=0.361)$ or the number of children $(\mathrm{p}=0.616)$ (Table 2).

TABLE 2. Values of Spearman correlation coefficient.

\begin{tabular}{llc}
\hline \hline \multirow{2}{*}{ Age } & Correlation coefficient & $\begin{array}{c}\text { Frequency of breast } \\
\text { self-examination }\end{array}$ \\
\hline \multirow{2}{*}{ Place of residence } & Significance (bilateral) & -0.049 \\
\hline \multirow{2}{*}{ Education } & Correlation coefficient & 0.717 \\
\cline { 2 - 3 } & Significance (bilateral) & 0.154 \\
\hline \multirow{2}{*}{ Number of births given } & Correlation coefficient & -0.122 \\
\cline { 2 - 3 } & Significance (bilateral) & 0.361 \\
\cline { 2 - 3 } & Correlation coefficient & 0.067 \\
\hline
\end{tabular}

Most of the respondents considered various campaigns promoting the awareness of breast cancer necessary (72.9\%), while some $22 \%$ thought that it should be better. At the same time, some $3 \%$ of respondents have never heard of such campaigns and $1.7 \%$ did not provide an answer. Also, $91.5 \%$ of the respondents thought that the breast cancer screenings should be mandatowy, while $5 \%$ disagreed with it. Some $3.4 \%$ provided no answer. 
TABLE 3. Values of Spearman correlation coefficient.

\begin{tabular}{llc}
\hline \hline \multirow{2}{*}{ Age } & Correlation coefficient & $\begin{array}{c}\text { Frequency of breast } \\
\text { examination } \\
\text { at the gynecologist's }\end{array}$ \\
\hline \multirow{2}{*}{ Place of residence } & Significance (bilateral) & 0.039 \\
\hline \multirow{2}{*}{ Education } & Correlation coefficient & 0.773 \\
\cline { 2 - 3 } & Significance (bilateral) & -0.269 \\
\hline \multirow{2}{*}{ Number of births Niven } & Correlation coefficient & 0.041 \\
\cline { 2 - 3 } & Significance (bilateral) & 0.058 \\
\hline \multirow{2}{*}{ Age at first birth } & Correlation coefficient & -0.245 \\
\cline { 2 - 3 } & Significance (bilateral) & 0.064 \\
\hline & Correlation coefficient & 0.407 \\
\hline & Significance (bilateral) & 0.008 \\
\hline
\end{tabular}

Over $60 \%$ of women participating in the study declared that gynecologist never or almost never examined their breasts. Some $34.5 \%$ have usually undergone such examination, while only $5 \%$ of women had their breasts always examined. Residents of larger cities were more likely to have their breasts examined than residents of the countryside $(p=0.041)$, similarly to women who had their first pregnancy later in life $(p=0.008)$. There was no correlation between the frequency of these examinations and the respondent's age $(0.773)$, education $(\mathrm{p}=0.058)$ or the number of births given $(\mathrm{p}=0.064)$.

Some $45 \%$ of women took part in free check-ups for breast cancer, while some $42 \%$ have never had a mammography screening, since they were too young for it. In addition, $7 \%$ of the respondents had a screening at some private practice, while $5 \%$ have not had their breasts screened, even though their age qualified them to it.

Most women took part in the free screenings and they did so on a regular basis, as well as planned to continue doing it $(60 \%)$. Another $5 \%$ had regular screenings but they were unsure as to whether they would continue the screenings. Furthermore, almost $31 \%$ of the respondents have never had any screenings, even though they wanted to do them in the future. Some $4 \%$ of the respondents have never had any screenings and they also do not plan to take them.

Women at older age were more interested in regular screenings than younger individuals $(p<0.001)$. Also, residents of bigger cities were more interested in these $(p=0.031)$ and those women who conducted breast self-diagnoses more often $(p=0.012)$. There was no correlation between one's education and the answer provided $(\mathrm{p}=0.405)$.

TABLE 4. Values of Spearman correlation coefficient.

\begin{tabular}{llc}
\hline \hline \multirow{2}{*}{ Age } & & $\begin{array}{c}\text { Are you interested } \\
\text { in participating } \\
\text { in free screenings? }\end{array}$ \\
\hline \multirow{2}{*}{ Place of residence } & Correlation coefficient & -0.486 \\
\cline { 2 - 3 } & Significance (bilateral) & 0.000 \\
\hline \multirow{2}{*}{ Education } & Correlation coefficient & 0.291 \\
\hline Significance (bilateral) & 0.031 \\
\hline \multirow{2}{*}{\begin{tabular}{l} 
conduct breast exams? \\
\cline { 2 - 3 }
\end{tabular}} & Correlation coefficient & 0.115 \\
\cline { 2 - 3 } & Significance (bilateral) & 0.405 \\
\hline & Significance (bilateral) & 0.338 \\
\hline
\end{tabular}

The respondents pointed to the fear of discovering an illness $(62.5 \%)$, as one of the reasons why women do not conduct and rarely plan any screenings. Other than that, women may simply not know that it is possible (33.3\%), they do not have time for it $(21 \%)$, they are afraid of pain during the screening $(12.5 \%)$, they were influenced by their friend or acquaintances $(12.5 \%)$ or they are simply not interested $(8.3 \%)$.

Some $40 \%$ of the respondents claimed that junior high school curriculum should include a subject related to tumors (42.1\%). Some $22.8 \%$ of the respondents mentioned that such class needs to be introduced to primary schools, while $14 \%$ claimed that such subjects should be taught in high school. At the same time, another $18 \%$ claimed that every single woman should educate herself about it and one person (1.8\%) though this is unnecessary.

One of the main reasons why the respondents receive the preventive screenings is that they want to avoid the illness (77\%). Less respondents claimed that this was because the screening was free (43\%) and some did it because they were encouraged by various commercials or celebrities and social campaigns (10.7\%). Another 7\% did so because of an illness of a close person, while $16 \%$ of the respondents had no preventive screenings at all.

Most women (93\%) upon noticing any disturbing changes during breast self-examination would go to a doctor, while another $12 \%$ would look for solutions in the Internet or in literature. A little more than $5 \%$ of the respondents would do nothing and wait for other symptoms to arise, while 1 person would do nothing at all.

Almost 33\% of women had the mammography screening and the breast ultrasound, around $16 \%$ had the ultrasound only and $21 \%$ underwent mammography screening only. Some $31 \%$ of the respondents had no screenings at all. When it comes to women aged $25-35$, about $73 \%$ of them have never had any screenings. In case of individuals aged $36-45$, it is $50 \%$ and when it comes to women aged $46-55$, almost $85 \%$ of them had mammography and breast ultrasound and in case of the respondents aged 56-85, almost all of them had all screenings done. Worse results are achieved by women older than 65 .

Most respondents supported making breast examination mandatory for all women (91.5\%), while some 3.4\% of women were against it. The rest provided no answer.

Many participants in the study (75.4\%) thought that one of the ways to encourage women to examine their breasts is to freeze salary or benefits in case they did not want to undergo the examination. Some $16 \%$ of the respondents thought this would have no influence whatsoever, while $9 \%$ thought this would discourage even further.

\section{DISCUSSION}

Breast cancer might exert huge influence over the woman's health but also on her psyche. Women affected by this condition usually have a low self-esteem and they are concerned that their femininity is affected. Treating individuals with bad mental condition can be problematic for doctors. In spite of the hype about breast cancer, numerous prophylactic activities spreading the knowledge about the condition or encouraging women to do breast self-examination, it still remains a shameful disease. 
The authors' own findings show that breast self-examination is considered shameful as well. Many women have no idea how to do it or when to do it. Only some $22 \%$ of the respondents do the breast self-examination tests one a month and only $5.2 \%$ do it more frequently than once a month. A research study by R. Nita shows that some $17.4 \%$ of women over 35 regularly do the examinations [7]. Paździor had different findings - some $36 \%$ of Polish women regularly conduct the examinations [8]. Przestrzelska M. has show that only $12 \%$ of women do self-examination once a month [9] while others do it more rarely, which is a huge neglect of one's own health.

Residents of Otwock county point to the fact that there is a huge fear about the screenings, which is why women often resign from these check-ups. This was confirmed by Banach et. al. [10] or Smolen and Dobrowolska [11] who showed that fear is one of the reasons why women resign from these screenings. The authors' of this study have shown that some $62.5 \%$ of women resigned from the free medical check-ups, since they were afraid that doctors are going to detect some serious illness. This goes in keeping with findings of other authors. Women claim that the screening boosts the risk of cancer detection, which is still perceived as an incurable, mortal disease that does not go well with a scalpel. This partly explains why only some $45 \%$ of women took part in the free mammography screenings organized by the National Health Fund.

Since there are so many stereotypes about cancer, it is essential to spread the knowledge about various therapy programs. It is also important to speak openly about breast cancer and the risks it may cause and also encouraging medical staff to talk about it.

As the authors' own research shows, gynecologists in some $60.3 \%$ of cases never do a breast examination or usually do not do a breast examination. Midwives employed in primary care institutions never do breast examinations, apart from those in women postpartum period ( $1 \%$ of women) [8]. This is a dramatic situation, especially when one takes into account what Paździor suggests - only $19 \%$ of women receive information about breast cancer from their gynecologist [8]. Also, Lewandowska suggested it is $18 \%[12,13]$. According to the research by Paździor, only some 5\% of family doctors are sources of knowledge about breast cancers. According to the research by Smoleń and Dobrowolska, nurses provided such information to $16 \%$ of patients only (Subcarpathian Voivodeship) and $12 \%$ of patients in Ostrowiec Świętoktrzyski [8,11].

In February 2005, the Polish Gynecological Society issued some guidelines concerning a gynecological examination. In case of women older than 20 , it is recommended to:

- Conduct physical examination of the nipples and taking medical examination;

- Teach women palpation - a self-examination of the nipples;

- Encourage patients to inform a gynecologist as soon as possible, in case any changes appear in the nipples.

Even though these recommendations exist, most doctors never examine patients' breasts or even educate them how to do it. According to American Cancer Society, breast examination should become a routine examination conducted by gynecologists and general practitioners. It is the attitude of gynecologists and family doctors.

It is the attitude of gynecologists and family doctors, as well as nurses or pharmacists that mainly affects patients' attitudes toward breast cancer. Both various prophylactic measures and breast self-examination methods should be promoted among patients. It is the task of doctors, medical staff, pharmacists as well as any other individual that works with patients. Pharmacists should also become more involved in prohealth education, since women tend to feel so comfortable in pharmacies that they are able to tell about any worrying symptoms. A simple talk with the pharmacist might encourage the patient to take a preventive medical checkup . Pharmacists are individuals with medical expertise which means they have a chance to encourage women, dispel their doubts, answer their questions and, first things first, reducing their fear of medical procedures. They can also promote health-improving activities through distributing leaflets or brochures - as part of pharmaceutical care.

Screenings tend to provide the most accurate results but women are not too eager to undertake such check-ups. Should they be mandatory, much more women would take them, especially given the fact that some $91.5 \%$ of the study participants supported the idea of making breast examinations mandatory. Plus to that, some $75.4 \%$ of the respondents claimed that either a salary or social benefits freeze, in case of women who failed to take the compulsory check-up, would definitely encourage them to do so. These findings should be given a closer look, particularly in the context of increasing the attendance to preventive examinations. It is important to educate women in this regard, as well as talk about tumors in the media, so as to encourage them to participate in preventive checkups.

\section{CONCLUSIONS}

Judging by epidemiological data, Polish women are less likely to develop cancer, yet the death rate is higher than in rest of Europe. Looking at five-year survival rates and low prevalence, it is clear that breast cancer prevention programs are not effective enough. This pertains to primary prophylaxis, early detection and treatment of cancer [6]. Thanks to various research studies looking at genes responsible for hereditary breast cancer and BRCA1 or BRCA2 genes, there is a hope for improved early detection rates and providing medical care to patients suffering from the condition [14]. Women that have BRCA1 gene are at a higher $(90 \%)$ risk of developing breast cancer, while in half of women over 50 that have BRCA1, the tumor is almost bound to appear [15]. Members of that group should be subject to systematic prophylaxis and better educated about breast tumors.

At the moment, medical professionals, including general practitioners or gynecologists pay little attention to breast cancer preventive measures. Yet, they may provide huge help in early detection of breast cancer - there are still many women who do not conduct breast self-examinations. Pharmacists can also be of huge help, educating women by distributing leaflets and brochures, as well as answering questions (sometimes shameful) related to this issue.

Most women think that campaigns against breast cancer are indeed essential and they are interested in continuing them. Still, there is the fear of medical procedures or the risk that some disease might be detected, which is why numerous women avoid examinations at all. Educating patients should involve explaining that cancer detected at an early stage has very high odds of being cured.

Anti-cancer education could be implemented in primary school or junior high school -at an age, when girls have their 
first period. Teaching young girls about breast self-examination could prove necessary.

It might be a good idea to introduce mandatory screenings - most women consider them as encouraging to take regular check-ups.

\section{REFERENCES}

1. Krajowy Rejestr Nowotworów

2. Mazowiecki Rejestr Nowotworów

3. Bucholc M, Łepecka-Klusek C, Karauda M, et al. Personel medyczny wobec edukacji kobiet $\mathrm{w}$ zakresie samobadania piersi. Zdr Publ. 2003;113(3/4):230-3.

4. Graja T, Grodecka-Gazdecka S. Czynniki wpływające na jakość życia kobiet leczonych z powodu raka piersi. Prz Gin Poł. 2005;5(3):115-20.

5. Chmaj-Wierzchowska K, Olejniczak T, Rabiega D, et al. Ocena profilaktyki chorób kobiecych i zachowań prozdrowotnych wśród żeńskiego personelu medycznego. Prz Gin Poł. 2005;5(3):125-9.
6. Sytuacja zdrowotna ludności Polski. Państwowy Zakład Higieny. Warszawa; 2012.

7. Nita R, Łeśniczak B, Słomka B, et al. Wiedza i zachowania zdrowotne kobiet $\mathrm{z}$ województwa łódzkiego w zakresie profilaktyki raka piersi. Pielęg XXI w.2010;1-2(30-31):5-8.

8. Pażdzior A, Stachowska M, Zielińska M. Wiedza kobiet na temat profilaktyki raka piersi. Now Lek. 2011;80(6):419-22.

9. Przestrzelska M, Knihinicka-Mercik Z, Kazimierczak I, et al. Zachowania zdrowotne kobiet profilaktyce nowotworu szyjki macicy i sutka. Onkol Pol. 2006;9:172-5.

10. Banach M, Grabiec M. Miejsce edukacji zdrowotnej w profilaktyce onkologicznej. Ann UMCS sectio D. 2005;60(16):1-4.

11. Smoleń E, Dobrowolska B. Wiedza pielęgniarek województwa lubelskiego i podkarpackiego w zakresie czynników ryzyka nowotworów piersi. Med Og Nauk Zdr. 2014;20(1):6-11.

12. Lewandowska A, Mess E, Laufer J. Profilaktyka raka piersi wśród kobiet. Onkol Pol. 2011;1:131-4.

13. Czekanowski R. Choroby gruczołu sutkowego. Menopauza. HTZ. Warszawa: Wyd. Med. Borgis; 2003.

14. Ślubowski T, Ślubowska M. Biomarkery w raku piersi. Część I. Receptory, czynniki wzrostu, geny i onkogeny. Wsp Onkol. 2007;11(4):167-74.

15. Kordek R. Co to jest nowotwór? In: A. Jezierski. Onkologia. Warszawa: PZWL; 2005. p.11-28.

\section{Corresponding author}

Prof. dr hab. Dariusz Matosiuk

4A Chodźki Str., 20-093 Lublin, Poland

E-mail: dariusz.matosiuk@umlub.pl 